ROCZNIK ADMINISTRACJI PUBLICZNEJ 2019 (5)

KOMUNIKATY / STUDY REPORTS

DOI 10.4467/24497800RAP.19.018.11483

http://www.ejournals.eu/RAP/

ISSN 2449-7800 (online), ISSN 2449-7797 (print), p. 284-293

Natalila Zadyraka ${ }^{1}$

\title{
Grounds for the Presence of Public Property Legal Regimes: Experience of EU Member States Useful for Ukraine
}

\section{Problem statement}

Both the multidimensionality of the public property legal regime in political, socio-economic and the legal dimension and its public (administrative-legal) aspect influence the formation of good practice in implementing administrative law by relevant institutions. However, the essential characteristics of the legal regime in question are not developed well enough, at the doctrinal level in particular.

In 2014, the local government reform in Ukraine triggered the transfer of powers and financial recourses from central-level bodies to localgovernment ones as well as the establishment of new executive bodies of local government, namely communities. Today, the system of governance in Ukraine is decentralised: most of public matters of the state and society are resolved at the level of local government. Therefore, it is considered topical to establish grounds for the emergence of a property legal regime with rights acquired by public administration units in a decentralisation process. In this respect, it is crucial to be guided by the institutional dimension of the public administration activity covering the outcomes of the exercise of power by public and non-public bodies, in particular the state executive power and local government bodies.

The objective of the article is to describe the essential characteristics of the grounds for the presence of the public property legal regime, namely, within the limits of public legal succession.

\section{Presentation of basic material}

As a rule, there are the following grounds for the emergence of a public property legal regime: the acquirers' legal status of the right to such property, procedural aspects of the determination of the acquiring mechanism and peculiarities of such legal regime implementation, taking into account

1 Nataliia Zadyraka, PhD in Law Science, Associate Professor at Administrative Law Department, Faculty of Law, Taras Shevchenko National University of Kyiv. 
interests of the Ukrainian people. Based on O. I. Nastina's approach, the grounds for the presence of the public property legal regime may be classified according to the following criteria: will characteristics - forced (with no will of a previous property owner) and unforced; ways of emergence initial, primary, derivative and individual; ways of acquisition - historic (capture [occupation] of property by the state), primary (proclamation of the Ukrainian people's property item with further legislative consolidation of rights to that property), general (legal facts denoting the transfer of rights to the property to the state), special (legal facts denoting the transfer of rights to the property to the state with the simultaneous termination of communal property rights), specific (nationalisation, expropriation, requisition, transfer of right under cultural heritage items purchased by the state), individual (transfer [giving back] of land plots of common ownership that are not subject to sharing to state property); the ownership form of the entity the property right of which is terminated), private (in case of private property termination), public (in case of communal property termination) ${ }^{2}$.

It it worth noting that in terms of identification of the nature of a public property legal regime one should be guided, first of all, by the administrative-legal essence of legal norms regulating relevant procedures. This is particularly topical in the context of a large number of relations of private-legal nature when using public property. In fact, there may be relations in the implementation of legal protection and public property protection combining both public-legal (administrative) and private-legal elements. Thus, public administration units within the functioning of such a property legal regime may act in a private-legal form implementing public-legal decisions. It is practical to apply two-level and special legal theories to establish the legal nature of the relations described.

As R. S. Melnyk and V. V. Dzharty note, within the framework of the two-level theory, one should be guided by decision-making levels such as: 1) level one (answers the "if" question): the decision of a public administration unit, if it acts, is a public-legal one; 2 ) level two (answers the "how" question): the type and the way of how a public administration unit acts may be public-legal (administrative) and private-legal ${ }^{3}$. As for the specification of the legal nature of legal norms in case of the presence of a public property legal regime, it is advisable to use a special-legal theory. In particular, such legal norm has public-legal (administrative) essence that, in

2 O.I. Nastina, The right of state ownership of land in Ukraine: the author's abstract. Thesis, 12.00.06. K., 2011, p. 17-19.

3100 answers to 100 questions on Common Administrative Law, R.S. Melnik (ed.), K.: Yurinkom Inter, 2017, p. 45-50; V.V. Dzharty, Management of objects of state property in Ukraine: legal nature and implementation mechanism, monograph, X.: Disa plus, 2014, p. 174-177. 
the case of its application, authorises or binds public administration units solely with relation to a relevant act or decision ${ }^{4}$.

Specifying the characteristics of the legal nature of grounds for the presence of a public property legal regime, it should be clarified that the authorised persons in the field of use of such property acquire relevant competence in terms of the application of both public-legal and privatelegal instruments of public administration activity. As a result, administrative-legal and private-legal relations may arise, be changed or terminated. Moreover, the clearly displayed administrative-legal nature of legal norms is shown in the context of preparing activities in public property use (for example, preparation before privatisation) as well as establishing institutional and functional boundaries, planning, setting the terms and order of legal protection, and adopting administrative acts related to the said property. Alternatively, the transactional demonstrations of a public property legal regime may quite often be of private-legal nature within the framework of general competence demonstration. For instance, it refers to the sale of public property (shares) owned by the state, a whole property complex of a state enterprise, shares, including a controlling stake in a jointstock company, privatised items, etc.) at (international) stock markets, including in the form of depositary receipts, at auctions, on tender, including with an open price offer and in another competitive way available to the public.

Developing the opinion formulated above, the mandatory nature of the grounds for the presence of a public property legal regime is another crucial aspect of understanding the legal nature of the grounds for the presence of a public property legal regime regarding the ways of the emergence and implementation of powers of authorised persons as for the use of public property exclusively in the manner, within the limits and on the basis of law with the dominance of public interest in the relations indicated ${ }^{5}$. Hence, in case of the presence of a public property legal regime, the relevant basic institutional (subjective-objective), functional, and instrumental characteristics of the mechanism of administrative-legal support for the implementation of legal regimes of certain types of public property are institutionalised. Accordingly, the mechanism can be implemented within the framework of administrative-legal relations in that manner.

Nevertheless, it is important to take into account the contractual form of grounds for the existence of a public property legal regime in conjunction with regulatory and administrative acts, acts-actions and actsplans being the instruments of public administration activities. According to S. Skvortsov, it results from the following principal aspects: the existence

4 E. Forsthoff, Lehrbuch des Verwaltungsrechts, 9, neubearbeitete Auflage, München: C.H. Beck'sche Verlagbuchhandlung, 1966, p. 48-51.

5 Fundamentals of Administrative Justice and Administrative Law, R.O. Kuibida, V.I. Shishkin (eds.), K.: The Old World, 2006, p. 103-105. 
of a binding nature of relations; formal equality, reciprocity of rights and obligations of the subjects of such relations; voluntariness of obligations taken; predominance of organisational functions, the management-byobjective methods of management organisation; mutual control over the implementation of management goals and tasks established ${ }^{6}$.

In particular, when a public property legal regime occurs due to the formal equality of subjects of relations, a space is created for the formation of coordination relations, when joint actions provide an adequate level of public property legal protection. In this view, the mandatory nature of such relations is institutionalised, taking into account the mutual direction of the relations described. At the same time, due to the special-purpose nature of the activity, the parties are given opportunities to independently carry out the functions of planning and material-technical provision and financing in case of compliance with contractual obligations in terms of using public property. As a result, the voluntariness level of the obligations taken by public administration with regard to legal protection and protection of public property increases when the burden of bureaucratic procedures decreases and the coordination component of the public property legal regime increases with the state's simultaneous approval its own responsibility.

It follows from the above that the state, as a political sovereign represented by public administration, may, through legislative acts, establish the limits of its rights to public property, as well as the fact that certain grounds for the presence of the public property legal regime can be used only by the state. In this regard, it is also right to support A.V. Vinnytskyis attitude concerning the fact that within the public property legal regime a reverse situation is also possible, when such a regime arises through the acquisition of powers related to the use of property mentioned by private law ${ }^{7}$.

This scenario is also possible when a public property legal regime occurs for third parties who regardless of their will and the desire of the police or its officials have become parties to legal relations concerning the use or utilisation of public property ${ }^{8}$. At the same time, in the event of the presence of a public property legal regime, the main participants in the relations are still public administration units, and all other categories of persons may be considered as additional participants. The latter often acquire such status for the purpose of indemnification for material or moral harm within the limits of a procedural or judicial dispute.

6 S.S. Skvortsov, "The place and functions of the administrative contract as a means of management activity in public administration”, State of Law, 2005, № 8, p. 78-82.

7 A.V. Vinnitskyi, "Participation of public establishments in property relations: problems of the balance of administrative-legal and civil-legal regulation", "Administrative and Municipal Law", 2010. № 11, p. 82-91.

8 I.V. Palamarchuk, "Public property as a means of exercising police powers: a thesis”, 12.00.07, K. Z., 2017, p. 6. 
Thus, an intermediate conclusion can be made that the grounds for the existence of a public property legal regime are based on the social legal relations established by administrative-legal norms, the content of which constitutes the powers of their subjects with relation to the implementation of management and the formation of organisational and legal conditions for the provision of proper, that is proper and functional, use of such property ${ }^{9}$. In this aspect, on the basis of the relation with legal norms it is worth distinguishing the following forms of management in the event of the presence of a public property legal regime: right establishment and right exercise (the establishment and application of legal norms) aimed at the provision and implementation of regulatory and administrative acts (the organisation of events and the implementation of logistics operations $)^{10}$. At the same time, a foundation is created for purposeful and consistent cooperation of individual and collective subjects of public and private law in terms of providing legal protection and protection of public property.

Describing the grounds for the existence of a public property legal regime, one should pay attention to the fact that the voluntary acquisition of rights to this property takes place mainly taking into account a legal category such as "public needs". Alternatively, the use of the category "social necessity" is typical of the mandatory procedure. Both of them are based on the need to meet public interest in the field of the efficient and proper use of public property. In this sense, it is necessary to draw attention to the fact that it is a common trend in the national law of foreign countries to strengthen the role of the social component of public interest in establishing the grounds for the presence of a public property legal regime. Consequently, as M. Galiatin states, it is about "social suitability or social interests" in Spain, "common interests" in Italy, "public good" in Germany, "important public interests" in Sweden, "public interests" in Portugal, in the USA - "social valuable goal"11. In fact, the characteristics of the grounds for a public property legal regime described are based on the sociocentric collective dimension of relations in the field as well as the necessity to achieve the public good as a combination of private interests of public property users. Nevertheless, the fact mentioned above does not exclude the possibility that such a teleological category is an evaluative concept and has to be clarified taking into account national realities.

Thus, the category of public interest has been used in Ukraine as a priority and meant the foundation for all other types of interests since

9 Y.D. Kuchinskyi, "Administrative-legal regime of military property in Ukraine: a thesis", 12.00.07, K., 2017, p. 128.

10 V.M. Bevzenko, Management of the Nature Reserve Fund of Ukraine (organisational and legal issues): monograph, Kherson: Ailant, 2005, p. 57.

11 M.Y. Galyatin, The USA: Legal Regulation of Land Use, M.: Science, 1991, p. 40. 
Soviet times ${ }^{12}$. In this view, it can be said that public interest is seen here as identical with social interest, namely nationwide. It should be noted immediately that from the logical point of view this is not entirely correct, since public interest also covers state-wide interest, taking into account the interests of territorial communities in view of the latest reform of decentralisation of the administrative-territorial system at national level. Accordingly, K.Y. Totiev rightly clarifies that for the achievement of the social goal, the public nature of interest means that society is an integral entity where the highest level of community is represented by the interests of the whole society through the basic needs of people, conditioned by the need for social development ${ }^{13}$. Consequently, the key characteristic of public interest in the presence of a public property legal regime is its focus on taking into account social needs, in spite of fragmentary corporate or group interests, as well as that purely of the state.

As for the public interest represented in the activities of public administration units in terms of the existence of a public property legal regime (depending on the axiological colouring), the implementation of two scenarios for the further use of such property cannot be excluded. Firstly, it may concern a protective function according to the anarchistlibertarian ideal of the "state as a night watchman"14. Secondly, one can lobby for the interests of certain social groups or corporations through the state apparatus separated from civil society. At the same time, the practice of radical etatism or consciously ignoring the legitimate principles of the functioning of public administration is not in line with the latest standards of the concept of "good governance". Therefore, implementing a public property legal regime in accordance with the principle of law supremacy as well as meeting social needs and interests in terms of the formation and development of a welfare state are seen as a reasonable way for public administration. As a result, there is a dialectical interaction of state and social interests within the framework of a public property legal regime.

Thus, public interest plays a decisive role for the occurrence of a public property legal regime at national level. Furthermore, in the Ukrainian realities of administrative law reform it is necessary to focus on a society-wide spectrum of the public interests of public property users. At constitutional level, it is confirmed by legal provisions contained in the Constitution concerning the necessity of taking into account the following types of public interest: national interests (Article 18), state interests (Part 2, Article 121); national security interests (Part 2 Article 32, Part 3 Article 34, Part 2 Article 39), public order interests (Part 23 Article 34, Part 2 Article 35, Part 1

12 A.V. Kriazhkov, "Public interest: concept, types and protection", State and Law, 1999, № 10, p. 91.

13 K.Y. Totiev, "Public Interest in Legal Doctrine and Legislation", State and Law, 2002, № 9, p. 25.

14 R. Nozick, Anarchy, state and utopia, N.Y.: Basic Books, 1974. XVI, p. 26-27. 
Article 36, Part 2 Article 39); territorial integrity interests (Part 3 Article 34); society's interests (Part 7 Article 41, Part 4 Article 89); interests of all fellow citizens (Part 3 Article 79; Part 3 Article 104); interests of human rights (Part 2 Article 32, Part 1 Article 36); interests of economic well-being (Part 2 Article 32); common interests of territorial communities of villages, settlements and cities (Part 4 Article 140) ${ }^{15}$. In view of this, a correlation of such provisions with an understanding of public interests in common law can be seen displayed in the common regularity of relations between public administration and citizens not through legislation boundaries but, primarily, by influencing relations through decision-making ${ }^{16}$.

Moreover, it is worth taking into account new trends in the field of public legal succession in using public property. At the doctrinal level, the above-mentioned term is considered as a process of power delegation ${ }^{17}$, acquisition of administrative competence from one public administration body to another ${ }^{18}$ within the functions assigned by the state ${ }^{19}$. In this context, one could consider Articles 55 and 56 of the Constitution of Ukraine ${ }^{20}$.

Here, legal succession takes place not only within common competence but also in property relations concerning specific managerial (organisational) content of rights and obligations ${ }^{21}$. In addition, as the of the Supreme Administrative Court of Ukraine clarifies in paragraph 9 of its Resolution on the practice of using certain provisions of the Code of Administrative Legal Procedure of Ukraine by administrative courts during the consideration of administrative cases of 6 March 2008 \# 2 - in an analogy to procedural legal succession - the perspective framework ("who is a legal successor in legal relations") as well as competence peculiarities (according to the

15 I.P. Andrushko, "'Public Interest' category in Constitutional Law: Concept and Content", Journal of the Kyiv University of Law, 2011, № 4, p. 138; Constitution of Ukraine of 28 June 1996, № 254K/96-BP, with amendments and additions as of 30 September 2016, Official Journal of Ukraine, 2010, № 72/1, special issue, p. 15, Article 2598.

16 S.A. Rukhtin, Forced seizure of land as well as other real estate in Russia, USA and Great Britain: Monograph, V.P. Kamyshansky (ed.), M.: Arctic 4D, 2007, p. 209.

17 M.M. Agarkov, Selected works on civil law: 2 volumes T. 2. M.: JSC Centre YurInfoR, 2002, p. 112.

18 V.M. Bevzenko, "Public legal succession", Administrative Law and Process, 2014, № 1 (7), p. 25.

19 E.N. Belei, "Legal grounds of legal succession of central executive power bodies", Scientific Bulletin of Kherson State University, 2016, issue 6, p. 33.

20 Constitution of Ukraine of 28 June 1996, № 254K/96-BP, with amendments and additions as of 30 September 2016, Official Journal of Ukraine, 2010. № 72/1, special issue, p. 15, Article 2598.

21 P. Povar, "Legal succession in the formation and termination of executive power central bodies", Bulletin of Kyiv Taras Shevchenko National University, Law Sciences, 2012, issue 93, p. 40-43. 
"scope of competence" of the public administration body) should be taken into account ${ }^{22}$.

It is then necessary to focus on such legal facts as merger, acquisition, division, transformation and liquidation with a subsequent transfer of competence to another public administration body for the presence of a public property legal regime based on public legal succession. Such a transition may take place both within administrative procedures and under the rules of administrative jurisdiction when considering and resolving relevant cases. It should be remembered that such legal succession may be either absolute or selective according to the criterion of the completeness of legal succession. A full transition of powers to the newly created Supreme Court on public administration of public property belonging to the Supreme Court of Ukraine could be given as an example.

\section{Conclusions}

It can be ascertained that a public property legal regime may take place in view of the specific nature of the subject's acquisition of rights to such property. In the present case, it refers to a willed, active and often unilateral procedure of institutionalisation of a public property legal regime, taking into account public interest in the legal relations mentioned above. In this perspective, it would be reasonable to postulate the delegation by the Ukrainian people of a legally enforceable right to exercise the competence related to the implementation of legal protection and use of public property to public administration bodies. For this purpose, there should be a clearly defined system of special legal norms not only for establishing the grounds for the existence but also for the implementation and termination of relevant relations in the field of public property, as it is the case in EU Member States.

\section{Bibliography}

100 answers to 100 questions on Common Administrative Law, R.S. Melnik (ed.), K.: Yurinkom Inter, 2017.

Agarkov M.M., Selected works on civil law: 2 volumes T. 2, M.: JSC Centre YurInfoR, 2002.

Andrushko I.P., “'Public Interest' category in Constitutional Law: Concept and Content", Journal of the Kyiv University of Law, 2011, $\mathrm{n}^{\circ} 4$.

22 On the practice of application of certain provisions of the Code of Administrative Legal Procedure of Ukraine during the consideration of administrative cases by administrative courts: Resolution of the Plenum of the Supreme Administrative Court of Ukraine of 6 March 2008, $\mathrm{n}^{\circ}$ 2, Bulletin of the Supreme Administrative Court of Ukraine, 2008, nº 2, p. 117. 
Belei E.N., "Legal grounds of legal succession of central executive power bodies", Scientific Bulletin of Kherson State University, 2016, Vol. 2. Issue 6.

Bevzenko V.M., Management of the Nature Reserve Fund of Ukraine (organisational and legal issues): monograph. Kherson: Ailant, 2005.

Bevzenko V.M., "Public legal succession", Administrative Law and Process, 2014, no 1 (7).

Constitution of Ukraine of 28 June 1996, no 254K/96-BP: with amendments and additions as of 30 September 2016, Official Journal of Ukraine, 2010, no 72/1, Special issue. P. 15. Article 2598.

Dzharty V.V., Management of objects of state property in Ukraine: legal nature and implementation mechanism: monograph. X.: Disa plus, 2014.

Forsthoff E., Lehrbuch des Verwaltungsrechts, 9, neubearbeitete Auflage. München: C.H. Beck'sche Verlagbuchhandlung, 1966.

Galyatin M.Y., The USA: Legal Regulation of Land Use, M.: Science, 1991.

Kriazhkov A.V., "Public interest: concept, types and protection", State and Law, 1999, no 10.

Kuchinskyi Y.D., "Administrative-legal regime of military property in Ukraine: a thesis", 12.00.07. K., 2017.

Kuibida R.O., Shishkin V.I. (ed.), Fundamentals of Administrative Justice and Administrative Law, K.: The Old World, 2006.

Nastina O.I., "The right of state ownership of land in Ukraine: the author's abstract", Thesis, 12.00.06. K., 2011.

Nozick R., Anarchy, state and utopia, N. Y.: Basic Books, 1974. XVI.

Palamarchuk I.V., "Public property as a means of exercising police powers", Thesis, 12.00.07. K. Z., 2017.

Povar P., "Legal succession in the formation and termination of executive power central bodies", Bulletin of Kyiv National University named after Taras Shevchenko, Law Sciences, 2012, Issue 93.

Resolution of the Plenum of the Supreme Administrative Court of Ukraine of 6 March 2008, $\mathrm{n}^{\circ}$ 2, Bulletin of the Supreme Administrative Court of Ukraine, $2008, n^{\circ} 2$.

Rukhtin S.A., Forced seizure of land as well as other real estate in Russia, USA and Great Britain: Monograph, V.P. Kamyshansky (ed.), M.: Arctic 4D, 2007.

Skvortsov S.S., "The place and functions of the administrative contract as a means of management activity in public administration", State of Law, 2005, $\mathrm{n}^{\circ} 8$.

Totiev K.Y., "Public Interest in Legal Doctrine and Legislation", State and Law, 2002 $\mathrm{n}^{\circ} 9$.

Vinnitskyi A.V., "Participation of public establishments in property relations: problems of the balance of administrative-legal and civil-legal regulation", Administrative and Municipal Law, 2010, $\mathrm{n}^{\circ} 11$. 
Abstract

The article describes the legal regime for the creation of public property rights in Ukraine. It also highlights the need for further development of this regime in accordance with European standards.

Keywords: creation of public property rights, public interest, Ukrainian legal system

Przyczyny istnienia systemów prawnych regulujących kwestie mienia publicznego: doświadczenia państw członkowskich UE przydatne dla Ukrainy

Streszczenie

$\mathrm{W}$ artykule opisano system prawny zapewniający tworzenie praw własności publicznej na Ukrainie. Podkreślono również konieczność dalszego opracowywania takiego systemu zgodnie ze standardami europejskimi.

Słowa kluczowe: tworzenie praw własności publicznej, interes publiczny, ukraiński system prawny 